\title{
Influence of Competency and Partnership to Performance in Small Business in the Field of Culinary in North Bandung Area
}

\author{
Asep Kurniawan' ${ }^{1}$, Andri Irawan², Yun Yun ${ }^{3}$ \\ \{asep.kurniawan@lecture.unjani.ac.id ${ }^{1}$, andri.irawan@lecture.unjani.ac.id ${ }^{2}$, \\ yunyun@lecture.unjani.ac.id $\left.{ }^{3}\right\}$ \\ 1,2,3 Universitas Jenderal Achmad Yani, Jl. Terusan Jenderal Sudirman Cimahi, Jawa Barat, Indonesia
}

\begin{abstract}
SME performance is a desired outcome and expected by SMES for its business continuity. One of them is on the business of culinary field, where the culinary business in the area of North Bandung is now growing. One of the causes that influence the performance of SMES is entrepreneurship and partnership competence. This research aims to determine the influence of entrepreneurship competence and partnerships with SMES performance. Models used use partial least square-Structural Equation Modeling (SEM). The population and samples in this study were 75 small business perpetrators in the area of North Bandung. The results of the study showed that respondents responses to competencies, partnerships and performance were in high category while competence had a greater influence on performance through partnerships.
\end{abstract}

Keywords: Competence, partnerships, performance

\section{Introduction}

In the national economic system has shown that SMES in fact are more resistant to various threats due to the economic crisis. The presence of small businesses in the middle of the Indonesian economy turned out to show SMES are still able to absorb a lot of manpower, in addition SMES can also improve the PBD, contribute to the funds of APBN and APBD from taxes paid by SMES, as well as Able to develop the business world. This encourages government and business actors to make efforts in the development of SMES or small and medium industry sectors. [1].

SMES are able to increase GDP and contribute to absorb manpower. SMES in Indonesia in 2017 reached 815.717 business units. The amount is $1.29 \%$ of total business units in Indonesia as a whole. SMES also contributes to employment provider and absorbs 9.4 million workforce or $7.85 \%$ of total business units in Indonesia. Similarly, the role of SMES in the creation of the national gross domestic product (GDP) according to the prevailing price is 2,976.646 trillion rupiah in the year 2017. So the role of SMES in the national economic system is no doubt [2]

North Bandung is one of the areas in West Bandung regency that has a high growth potential. West Bandung Regency average expenditure per month for food and beverages amounting to Rp. 425,883,- [3]. Gross product contributions for food and beverage 
accommodation in West Bandung Regency are increasingly increasing, so small businesses of food and beverage fields must be able to capture opportunities that will ultimately increase performance and competitiveness Small business actors in West Bandung Regency while the number of SMES in West Bandung Regency is as many as 155,041 units with labor absorption of 277,183 people. The number of businesses engaged in food and beverage is as many as 23,731 units with a labor absorption of 35,401 people. [4]

Culinary businesses should be able to improve their competence and expand partnerships so that high opportunities can be utilized quickly and well in the efforts to develop and grow their business. However, there are many obstacles that occur in relation to the competencies that are owned especially small businesses are still low managerial capabilities and decision making by small businesses that make their business Developed because of the weak ability to establish partnerships owned by the business actors so that the performance of small businesses is not maximized and impactful difficulty achieving a competitive advantage, as delivered from research [5] conducts research in Cimahi and Bandung, small businesses in the field of culinary sector still lacking in its competence in the field of organizing competencies, strategic competencies and conceptual Competencie. The deficiency will certainly inhibit the sustainability of business from small businesses in the culinary field in Cimahi and the city of Bandung. Business actors should be able to improve their business competence and able to implement the right strategy, especially in the increasingly tight competition in the field of food and beverage business.

Competition in the food and beverage industry demands a high level of competence and high capability in establishing partnerships to improve the performance of small business people in food and beverage field so it is expected to increase the value of The resulting product. Based on the explanation on the central issue of this research performance of small business actors field of food and beverage have not maximal in because still low competence and still low ability in establishing partnership. So that researchers are interested in conducting research on the influence of competence and partnership on the performance of small business people in the area of North Bandung.

\section{Literature Review}

\subsection{Competence}

Competence that one has is the knowledge and skills that have to implement and/or to support the implementation of the work, which is the basis for the creation of value in an organization, [6]. While[7] explained that competences can be routine job skill and knowledge which could be considered to be competences or wider characteristics that are supposedly required in the work place. Next according to Spencer and Spencer in [8] Explains that competence is the underlying characteristic of a person relating to the effectiveness of individual performance in its work or the fundamental characteristics of an individual who has a causal relationship or as a causation with the criteria is used as a reference, effective or performing prime or superior in a particular workplace or situation.

The definitions of the above experts can be concluded that competence is a fundamental characteristic of the individual that is possible to provide superior performance in a particular job, role, or situation. Competence is also the integration of knowledge, skills, and attitudes that make it possible to implement an effective way.

Competencies are formed from five characteristics: motives, traits, self concept, knowledge, dan skill, [9] in [10] While entrepreneurship is a Entrepreneurship is a process in 
which new entrepreneurial opportunities and their implementation in marketable products and services are identified, [11].

In achieving its success, an entrepreneurial has certain traits, including openness, freedom, broad views, future-oriented, planning, belief, conscious, and respect for others and the opinions of others. Small businesses of culinary field also need entrepreneurship competence. Entrepreneurial competencies can be interpreted Entrepreneurial competency is defined as the individual characteristics. Entrepreneur is a person who undertakes risk for gaining profit in the business venture [12]. The notion explains that entrepreneurial competence as an individual characteristic, entrepreneurs are the ones who take over the risks to benefit from the business they run.

Next [13] explains that the conceptual framework of study for entrepreneurial competence focuses on social and environmental factors that have been concluded in relationship competence, strategic competence, and commitment competencies. While according to Lado, et all in [14] Define entrepreneurial competence as the managerial capability of a firm's leaders to create and communicate a strategic vision for structuring inter-firm relations. Entrepreneurial competence is a managerial capacity of the company's leaders to create and communicate a strategic vision to build inter-firm relation. Entrepreneurial competence should be able to convey the vision of strategy to build internal company relationships. Entrepreneurs should be able to build good internal relationships in order to achieve the strategic vision to be achieved.

So that the entrepreneurial competency indicator used as size in this research is opportunity competency, organizing competencies, strategy competencies, social competencies, commitment competencies dan conceptual competencies. The six indicators will be used as a variable forming competence of small business people of culinary field in North Bandung area.

\subsection{Partnership}

Nowadays, many challenges and obstacles faced by SME actors are quite complex, not only related to the limitation of access to the various resources needed but also about the mentality and spirit of the SME actors. [15] In his research stated that partnerships give a good impact to the company in achieving its objectives. Partnerships have a positive and significant influence on small business performance by $84.3 \%$. Partnerships are one of the solutions to overcome the gap between small and large businesses. The growth of small business in Indonesia is not separated from its function as a partner of large businesses that are tied in a business partnership pattern. The strategic purpose of this partnership is to serve a common interest in improving network performance.

Next [16] Stating that the equal partnership, need and benefit mutually should be implemented in several stages, identifying small businesses that have the potential to grow rapidly, building small businesses to become self-reliant, Establishing business partnerships by developing a small, independent business as a subcontractor of a large industry. Partnerships can be hampered if large companies do the integration from upstream to downstream. This condition requires government involvement as a regulator.

So that the indicator of the partnership that is used in variable measurement in this research is access to capital, coaching, and the Association of Management and business mutually beneficial. 


\subsection{Performance}

The company's performance is an obsession that is always sought in achieving an organization. Performance is an important achievement as the benchmark success rate of the organization. Performance achievement in companies is expected to be achieved proportionally [15] While according to [17] firm performance is defined in terms of change in the level of sales and the value of assets.

The performance of small-medium enterprises is determined by several factors such as production efficiency, marketing strategy, or financial adequacy. But, there is one important factor for SME performance, the entrepreneurs themselves special characteristics [18].

The performance of the company/organization is a measurement about the extent to which the company can be managed and convey the value of the company to customers and other stakeholders [19]. The company's performance consists of seven dimensions:

1. Innovativeness: Product innovation generated by the company to meet the needs of Customers

2. Creativeness: The creativity of products produced by the company to meet customer needs

3. Competitiveness: The company's competitive state perceived by the customer

4. Effectiveness: The effectiveness of the company in executing strategies to achieve objectives Company.

5. Productiveness: Number of products, product quality, and timeliness of production in Meet customer needs

6. Efficiency: The company's efficiency in allocating its resources.

7. Profitability: The company's advantages are used for product development and enterprise development.

As for the indicators of the performance used in variable measurements in this research is the financial aspect of the current financial condition, the average amount of business profit per year, the turnover of sales owned, the average market And the growth of the year and non financial markets including customer perspectives (level of service quality, customer satisfaction, and market owned), internal business process perspectives (administration system, level of productivity Product quality) and learning and growth perspectives (employee operational Skills, employee commitment to develop business, technology use, entrepreneurial capabilities and product innovation capabilities)

\section{Research methods}

Associative research is the relationship and influence of one variable to another, highlighted by the opinion of [20] This associative descriptive research is a study aimed at knowing the influence or relationship between two or more variables. Analysis of this research is a small business of culinary field. Descriptive research focuses on a systematic explanation of the facts gained when research is conducted. Descriptive research is a study of the problems of the current facts of a population. The population in this study is all small business perpetrators in the field of food and beverage that is in the area of North Bandung. The number of samples set in this study was 75 respondents to small business perpetrators in the area of North Bandung. The analysis tool used is SEM Pls 


\section{Results and discussion}

The respondent's response to the statement regarding the research variable can be seen in the table below:

Table 1. Respondent's Response to Research Variables

\begin{tabular}{|r|l|c|}
\hline \multicolumn{1}{|c|}{$\begin{array}{c}\mathrm{N} \\
\mathrm{o}\end{array}$} & Variable & Criteria \\
\hline 1 & Competence & High \\
\hline 2 & Partnership & High \\
\hline 3 & Performance & High \\
\hline
\end{tabular}

Source : Data processed, 2019

Further to know the outcome of the influence of competence and partnership on performance can be seen in the image below:

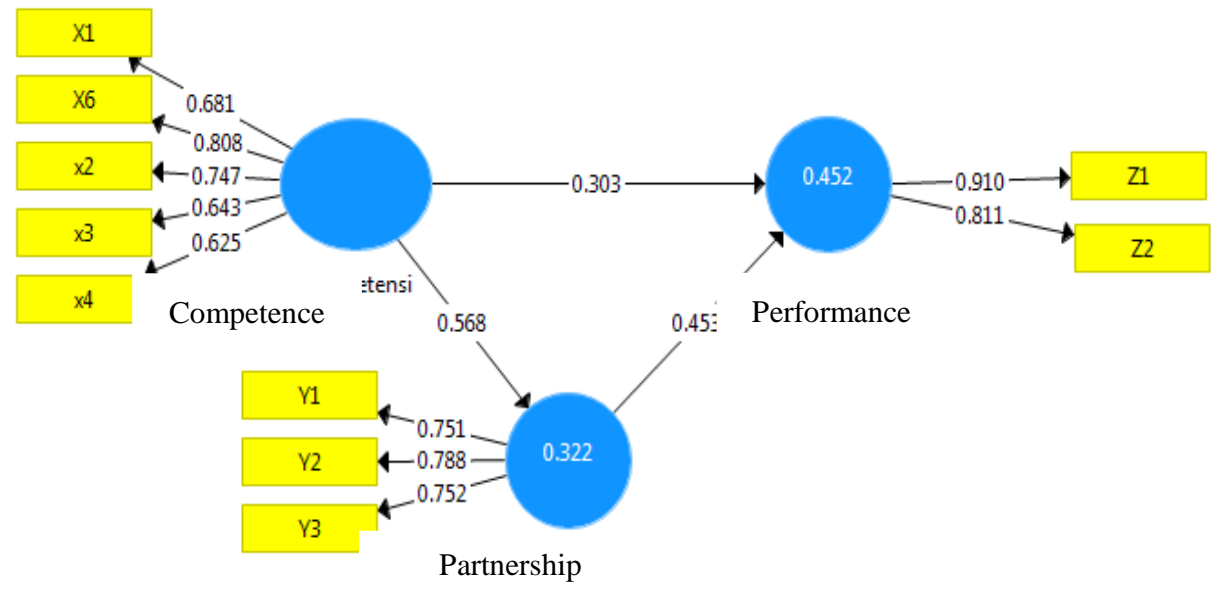

Fig 1. Influence of competency and partnership to performance in small business in the area of North Bandung

Based on the image above the correlation coefficient of competence to the performance of 0.303 it shows that the relationship between competence to performance belongs to the category enough. While the value of the correlation coefficient between the competencies to the partnership of 0.568 it shows that the relationship between competence to the partnership belongs to the strong category. Next the value of partnership correlation coefficient of performance of 0.453 it shows that the relationship between partnership to performance included in the strong category.

Furthermore, the influence of competence on partnerships is $32.26 \%$ while the effect of partnership on performance is $20.52 \%$. So that the total impact of competence on performance through partnerships is $52.78 \%$. Furthermore, the impact of competency on performance is $9.18 \%$. 


\section{Conclusions}

Based on the results and discussions that have been done that the response of respondents to competence, partnerships and performance are included in the high category. While based on the results of the calculations with the conclusion that the competency gives a direct influence of $9.18 \%$ to the performance, but the competency will influence the performance through a partnership of $52.78 \%$ on the perpetrators Small business of culinary field in North Bandung area.

\section{Acknowledgments}

The author would like to thank you for Rector Unjani Mr. Witjaksono, MSc, NSS ,; Chairman of LPPM Unjani Ibu Dr. Anceu Muniarti, SSi, MSi, and the Dean of the Faculty of Economics and Business Dr. Elis Dwiana Ratnamurni, SE, MP who has provided financial support for this research.

\section{References}

[1] "ukmdepok.co.id," 2017.

[2] "depkop," 2018. .

[3] "Kabupaten Bandung Barat Dalam Angka," 2016.

[4] "Kabupaten Bandung Barat Dalam Angka," 2018.

[5] A. et all Kurniawan, "Model Kompetensi Pelaku Usaha Kecil Bidang Kuliner di Kota Cimahi dan Kota Bandung.," 2016.

[6] H. Wulandari, J., Raharja, J. S., Muhyi, A. H., \& Nurasa, "Identifikasi Kompetensi Manajerial Pada Level Manajemen Menengah Dalam Industri Perbankan Indonesia," J. Siasat Bisnis, vol. 22, no. 1, pp. 20-37, 2018.

[7] J. Prestone, Competence Based Education And Trainging (Cbet) And The End Of Human Learning. Switzerland: Palgrave., 2017.

[8] D. Pianda, Kinerja Guru, 1st ed. Sukabumi: Cv Jejak, 2018.

[9] \& S. M. S. Spencer, Lyle M. JR., Competence at Work, Models for Superior Performance. John Willey \& Sons Inc., 1993.

[10] Sudarmanto, Kinerja dan Pengembangan Kompetensi SDM, 4th ed. Yogyakarta: Pustaka Pelajar., 2018.

[11] E. Innerhofer, E., Pechlaner, H., \& Borin, Entrepreneurship in Culture and Creative Industries. Springer, 2018.

[12] A. Kaur, Hardeep. Bains, "Understanding The Concept Of Entrepreneur Competency.," J. Bus. Manag. Soc. Sci. Res., vol. 2 No. 11, no. ISSN No: 2319-5614, 2013.

[13] H. J. Yeh, T. J., \& Chang, "A Multi-Case Study of Entrepreneurial Competencies in Microenterprises.," Int. J. Manag. Econ. Soc. Sci., vol. 7, no. 4, pp. 321-346, 2018.

[14] K. Khalid, Saba. Bhatti, "Entrepreneurial competence in managing partnerships and partnership knowledge exchange: Impact on performance differences in export expansion stages, "J. World Business., vol. WORBUS-728, p. 11, 2015.

[15] T. Suryana, "Pengaruh Lingkungan Eksternal, Internal dan Etika Bisnis terhadap Kemitraan Usaha serta implikasinya pada Kinerja Usaha Kecil," Kontingensi, vol. 2, no. 2 ISSN 2088-4877, 2014.

[16] I. Primiana, Menggerakkan Sektor Riil UKM \& Industri. Bandung: Alfabeta, 2009.

[17] N. Isaga, "The relationship of personality to cognitive characteristics and SME performance in Tanzania," J. Small Bus. Enterp. Dev., vol. 25, no. 4, pp. 667-686, 
2018.

[18] S. Purnomo, R. \& Lestari, "Pengaruh kepribadian, self eficacy dan locus of control terhadap Persepsi Kinerja Usaha Kecil dan Menengah," J. Bisnis dan Ekon., vol. 17, no. 2 ISSN : 1412-3126, pp. 144-160, 2010.

[19] S. Antony, J. P., \& Bhattacharryya, "Measuring Organizational Performance and Organizational Excellence of SMEs-Part 2: An Empirical Study on SMEs in India.," Meas. Bus. Excell., pp. 42-52, 2010.

[20] Sugiyono, Metode Penelitian Bisnis (Pendekatan Kuantitatif, Kualitatif dan $R \quad n D$ ). Bandung: Alfabeta, 2015. 